\title{
EFEKTIVITAS SEMANGGI AIR (Marsilea crenata) TERHADAP KADAR TSS PADA FITOREMEDIASI LIMBAH CAIR TAHU
}

\author{
Siti Musapana ${ }^{1}$, Endah Rita Sulistya Dewi ${ }^{2}$, Rivanna Citraning Rahayu ${ }^{3}$ \\ ${ }^{1,2,3)}$ Program Studi Pendidikan Biologi, FPMIPATI, Universitas PGRI Semarang \\ *Email : musapana8@gmail.com
}

Naskah diterima 23 Oktober 2020 dan disetujui 30 Oktober 2020

\begin{abstract}
Water clover is a type of aquatic plant, including weeds that are often found in rice fields or swamps, which can live in environmental conditions with low air quality. The purpose of this study was the effectiveness of water clover in reducing TSS levels in tofu wastewater. The research method used an experimental method with a completely randomized design (CRD) consisting of four variants of water clover biomass, namely $0 \mathrm{~g}, 25 \mathrm{~g}, 50 \mathrm{~g}$, 75 with 4 treatments 3 times repetitions for 10 days. The results showed that the TSS levels varied with a TSS value of 268.7; 221.3; 263; and 200.7. From these treatments, the effective TSS level to reduce was treatment 3 with 75 grams of biomass reaching $25 \%$. The homogeneity of variance test results showed that the four phytoremediation treatments of water clover plant had the same or identical (homogeneous) variances and the analysis of variance showed that Fcount> Ftable 5\% (4.07). This shows that HO is rejected and HI is accepted, which states that clover is effective for phytoremediation of tofu liquid waste. The conclusion of this research is water clover is effective in reducing TSS levels of tofu wastewater.
\end{abstract}

Kata Kunci : TSS, Effectiveness, Tofu Liquid Waste, Water Clover

\section{PENDAHULUAN}

Kegiatan industri tahu di Indonesia didominasi oleh usaha-usaha skala kecil dengan modal yang sangat terbatas, dimana sebagian besar industri tahu tidak memiliki unit pengolahan limbah dan biasanya limbah cair tahu langsung dibuang ke selokan atau badan air tanpa adanya pengolahan terlebih dahulu. Limbah cair tahu mengandung zat organik yang dapat menyebabkan pesatnya pertumbuhan mikroba yang ada di dalam air. Hal tersebut akan mengakibatkan kadar oksigen dalam air akan menurun sangat tajam, sehingga limbah cair industri tahu yang juga mengandung zat tersuspensi tersebut dapat mengakibatkan air menjadi kotor dan keruh (Subekti, 2011).

Pada umumnya, limbah cair industri tahu memiliki karakteristik berupa $\mathrm{pH}$, TSS (Total Suspended Solids), amonia, minyak dan lemak, nitrit, serta nitrat yang tinggi. Dari karakteristik tersebut masih melebihi baku mutu limbah cair yang ditetapkan. Secara fisik, limbah cair industri tahu yang berupa cairan kental berwarna putih keruh karena tingginya kandungan padatan tersuspensi dan berbau busuk karena tingginya kandungan zat organik (Faisal et al., 2015; Rahayu et al., 2017). TSS (Total Suspended Solid) atau total padatan tersuspensi adalah segala macam zat padat dari padatan total yang tertahan pada saringan dengan ukuran dari partikel maksimum 2,0 $\mu \mathrm{m}$ dan dapat mengendap (Widyaningsih, 2011).

Pada umumnya tumbuhan air yang mampu mengakumulasi seperti logam berat maupun zat organik dengan cara menyimpan pada bagian organ tertentu pada tanaman atau berpotensi sebagai agen fitoremediasi, misalnya Ipomea sp, Marsilea sp (Gupta et al., 2008). Logam berat yang mampu diserap oleh tumbuhan air antara lain: $\mathrm{Pb}$ (Timbal), Cd (Cadmium), $\mathrm{Cr}$ (Kromium), Hg (Merkuri), Zn (Seng) sedangkan pada zat organik yang mampu diakumulasi adalah protein, lipid, karbohidrat, dan lain-lain. Semua spesies tanaman air dapat melakukan penyerapan 
logam berat dan zat organik yang melalui dari akar yang dapat digunakan sebagai indikator pencemaran air. (Popova et al., 2009).

Semanggi air dapat ditemukan pada lahan yang basah seperti sawah kolam, rawa, sungai, yang merupakan dari habitat aslinya yang ada di perairan (Seth et al., 2008). Berdasarkan kisaran hidup tersebut tanaman semanggi air bisa berpotensi sebagai agen fitoremediasi pada limbah cair tahu. Tanaman air dapat memfilter dan mengabsorpsi pada partikel organik sekaligus mengabsorpsi ion-ion logam yang terdapat dalam air limbah yang melalui akar (Safitri, 2009). Selain tanaman semanggi yang kemungkinan dapat digunakan sebagai agen remidiator perairan yang terkontaminasi dengan limbah industri tahu, salah satu tumbuhan yang bisa sebagai agen fitoremediator yaitu semanggi air tumbuhan yang memiliki kemampuan untuk bisa mengolah limbah, baik itu berupa logam berat $\mathrm{Cd}$ dan $\mathrm{Cr}$ yang terdapat limbah cair, serta mampu beradaptasi pada lingkungan dengan kondisi salinitas yang rendah (<10\%) (Mcfarland et al. 2004).

Menurut Aslam (2017) fitoremediasi (phytoremediation) suatu sistem dimana tanaman tertentu dalam media (tanah, koral

\section{METODE PENELITIAN}

Perlakuan penelitian terdiri dari empat variasi biomasa tumbuhan Semanggi air (Marsilea crenata) yaitu : 0 gram (Kontrol), $25 \mathrm{~g}, 50 \mathrm{~g}$, dan $75 \mathrm{~g}$ yang disusun secara acak dengan undian, sedangkan volume limbah adalah 5 liter untuk tiap perlakuan dengan 3 kali ulangan dan 4 perlakuan yang berbeda.

\begin{tabular}{|c|c|c|c|}
\hline 1 & 2 & 3 & 4 \\
P1U1 & P3U3 & P3U1 & P2U2 \\
\hline 5 & 6 & 7 & 8 \\
P2U3 & P3U2 & P2U1 & P1U3 \\
\hline 9 & 10 & 11 & 12 \\
P1U2 & P0U1 & P0U3 & P0U2 \\
\hline
\end{tabular}

Gambar 1. Denah Eksperimen dan air) dapat mengubah zat kontaminan (pencemar) menjadi berkurang atau tidak berbahaya bahkan bisa berubah menjadi bahan yang berguna secara ekonomi. Fitoremediasi memiliki keuntungan dibandingkan dengan proses yang lainnya karena biaya yang murah.. Pengoprasian serta perawatannya lebih mudah, mempunyai efesiensi yang cukup tinggi, dapat menghilangkan zat pencemar berupa lgam-logam dan bahan organik, serta dapat memberikan keuntungan seperti memberi keuntungan secara ekologis. Fitoremediasi merupakan proses teknologi yang dapat menggunakan tumbuhan untuk memulihkan tanah atau daerah yang terkontaminasi limbah (Surtikanti, 2011). Teknologi ini dapat ditunjang dengan adanya perbaikan menggunakan media tumbuh dan ketersediaan mikroba yang ada di tanah untuk meningkatkan efisiensi dalam proses degredasi bahan polutan dialirkan ke seluruh bagian tumbuhan, sehingga air menjadi bersih dari polutan (Surtikanti dan Surakusumah, 2011).

Tujuam dilakukan penelitian mengenai kadar TSS pada fitoremidiasi limbah cair tahu menggunakan tanaman Marsilea crenata dalam menurunkan kadar TSS pada limbah cair industri tahu.

\section{Keterangan:}

P0 : Biomassa Semanggi Air 0 gram

P1 : Biomassa Semanggi Air 25 gram

P2 : Biomassa Semanggi Air 50 gram

P3 : Biomassa Semanggi Air 75 gram

Jumlah Unit Percobaan

$=$ Perlakuan $\mathrm{x}$ ulangan

$=4 \times 3$

$=12$ unit percobaan

$\mathrm{U}=$ Ulangan

Angka kanan huruf = Pengulangan

Subjek penelitian yang diamati adalah tanaman semanggi air (Marsilea crenata) sebagai agen fitoremediasi dalam menurunkan kadar Amonia dan TSS limbah industri tahu. Penelitian dilaksanakan pada 
tanggal 18-27 November 2019 di kos Jl. Gajah Barat Semarang. Untuk uji Laboratorium dilakukan di Balai Laboratorium Kesehatan dan Pengujian Alat Kesehatan Provinsi Jawa Tengah.

\section{HASIL DAN PEMBAHASAN \\ Hasil Fitoremediasi Kadar TSS}

Berdasarkan dari hasil penelitian yang dilakukan menunjukkan bawa tanaman Semanggi air (Marsilea crenata) memiliki efektifitas dalam menurunkan kadar TSS pada limbah cair tahu. Adapun perbandingan biomassa tanaman Semanggi air yang digunakan dalam penelitian adalah $0 \mathrm{~g}, 25 \mathrm{~g}, 50 \mathrm{~g}$ dan $75 \mathrm{~g}$ menunjukkan hasil yang berbeda. Adapun efektivitas tanaman Semanggi air dalam menurunkan kadar TSS dapat dilihat pada tabel 1 .

Tabel 1. Efektivitas tanaman semanggi air dalam menurunkan kadar TSS

\begin{tabular}{|c|c|c|c|c|c|c|c|}
\hline \multirow{2}{*}{$\begin{array}{l}\text { Baku } \\
\text { mutu*) }\end{array}$} & \multirow[t]{2}{*}{ Perlakuan } & \multicolumn{3}{|c|}{ Ulangan } & \multirow[t]{2}{*}{ Jumlah } & \multirow{2}{*}{$\begin{array}{l}\text { Rata- } \\
\text { rata }\end{array}$} & \multirow{2}{*}{$\begin{array}{c}\% \\
\text { penurunan }\end{array}$} \\
\hline & & 1 & 2 & 3 & & & \\
\hline & $\mathrm{P} 0$ & 229 & 287 & 290 & 806 & 268,7 & 0 \\
\hline & $\mathrm{P} 1$ & 325 & 168 & 171 & 664 & 221,3 & 17 \\
\hline & P2 & 205 & 235 & 229 & 789 & 263 & 2 \\
\hline & P3 & 131 & 163 & 308 & 602 & 200,7 & 25 \\
\hline
\end{tabular}

Berdasarkan tabel 1. dapat dilihat bahwa efektifitas fitoremediasi semanggi air terhadap kadar TSS menunjukkan hasil yang bervariasi antara 268,7-200,7. Nilai efektivitas tertinggi terdapat pada perlakuan D dengan Biomassa tenaman Semanggi air 75 gram dengan penurunan kadar TSS mencapai $25 \%$ dengan nilai rerata TSS telah memenuhi baku mutu yaitu 200,7 mg/L sedangkan Nilai efektivitas terendah pada terdapat pada perlakuan A dengan Biomassa tanaman Semanggi air 0 gram dengan penurunan kadar TSS 0\% dengan rerata yaitu 200,7 mg/L.

Berdasarkan data tabel 1. maka dapat dibuat grafik rata-rata efektivitas fitoremediasi semnaggi air terhadap kadar TSS.

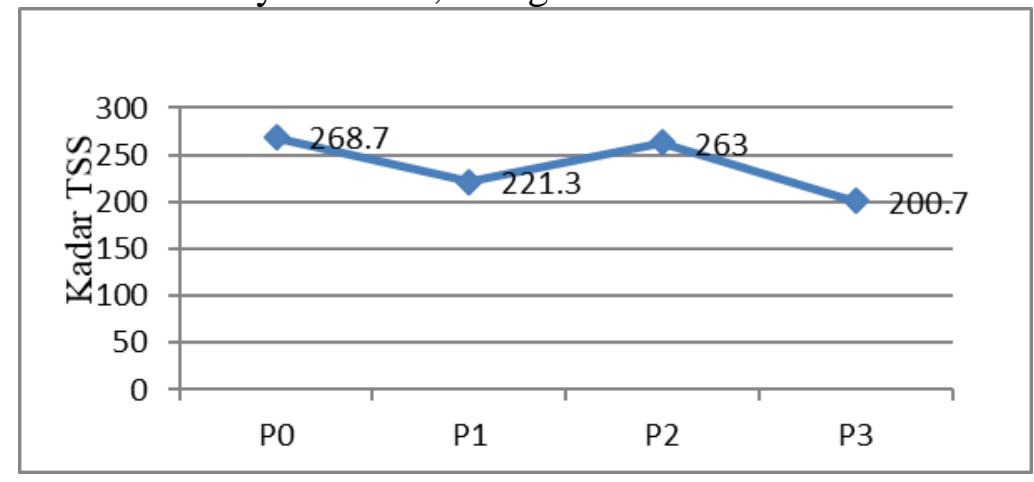

Gambar 1. Grafik rata-rata penurunan kadar TSS

\section{Uji Homogenitas varians}

Tabel test of homogeneity of varians digunakan untuk mengetahui variabel homogen atau heterogen dapat dilihat pada tabel 2 .

Tabel 2. test of homogeneity of varians TSS Fitoremediasi Semanggi Air (TSS)

\begin{tabular}{cccc}
\hline \multicolumn{4}{c}{$(\mathrm{TSS})$} \\
$\begin{array}{c}\text { Levene } \\
\text { Statistic }\end{array}$ & df1 & df2 & Sig. \\
\hline 4.765 & 3 & 8 & .034 \\
\hline
\end{tabular}

Berdasarkan tabel 2. maka homogenitas varians yang dihasilkan dengan nilai levene statistic 4.765 dan nilai sig 0,034>0,05 pada level probabilitas yang artinya keempat perlakuan evektivitas pada fitoremediasi pada tanaman semanggi air memiliki varians yang sama atau identik (homogen). 
Perhitungan homogenitas varians selanjutnya dilakuakan analisis sidik ragam. Hasil analisis sidik ragam (RAL) terhadap Analisis Sidik Ragam nilai TSS pada limbah cair tahu dapat dilihat pada tabel 3 .

Tabel 3. Analisis sidik ragam terhadap nilai TSS

\begin{tabular}{cccccc}
\hline $\begin{array}{c}\text { Sumber } \\
\text { Keragaman }\end{array}$ & $\begin{array}{c}\text { Derajat } \\
\text { Bebas }\end{array}$ & $\begin{array}{c}\text { Jumlah } \\
\text { Kuadrat }\end{array}$ & $\begin{array}{c}\text { Kuadrat } \\
\text { Tengah }\end{array}$ & $\begin{array}{c}\text { F } \\
\text { Hitung }\end{array}$ & $\begin{array}{c}\mathrm{F} \\
\text { tabel } \\
5 \%\end{array}$ \\
\hline Perlakuan & 3 & 7408.917 & 2469.639 & $573^{*}$ & 4.07 \\
Galat & 8 & 36786.000 & 4598.250 & & \\
Total & 11 & 44194.917 & & & \\
\hline$\left.{ }^{*}\right)=$ berbeda nyata atau signifikan pada taraf 5\%
\end{tabular}

Berdasrkan tabel 3. dapat diketahui bahwa $\mathrm{F}$ hitung $(573)>\mathrm{F}$ tabel 5\% $(4,07)$. Hal ini menunjukkan bahwa $\mathrm{H}_{0}$ yang menyatakan Tanaman Semanggi air tidak efektif terhadap penurunan pada kadar TSS pada fitoremediasi limbah cair tahu ditolak, maka $\mathrm{H}_{1}$ yang menyatakan Tanaman semanggi air efektif terhadap penurunan kadar TSS pada fitoremediasi limbah cair tahu diterima.
Untuk mengetahui perbedaan antara perlakuan tiap pengaruh biomassa tanaman Semanggi air terhadap efektifitas fitoremediasi kadar TSS pada limbah cair tahu dilakukan Uji lanjut yaitu dengan menggunakan Uji beda Jarak Nyata Duncan yang dapat dilihat pada tabel 4 .

Tabel 4. Uji beda Jarak Ganda Duncan TSS

\begin{tabular}{ccccccc}
\hline Perlakuan & Rerata & $\begin{array}{c}\text { Nilai } \\
\text { Duncan }\end{array}$ & & \multicolumn{3}{c}{ Selisih rata-rata setiap perlakuan } \\
\cline { 2 - 7 } & & $5 \%$ & P0 & P1 & P2 & P3 \\
\hline P0 & 268,7 & - & - & - & - & - \\
\hline P1 & 221,3 & 125,2 & $47,333^{*}$ & - & - & - \\
\hline P2 & 263 & 130,7 & $45,667^{*}$ & - & - & - \\
\hline P3 & 200,7 & 133,4 & $68,000^{*}$ & $20.667^{*}$ & $22.333^{*}$ & - \\
\hline $\begin{array}{l}\text { Keterangan : } \\
*\end{array}=$ Signifikan pada taraf 5 $\%$ & & & & \\
\end{tabular}

Hasil Uji Ganda Duncan (UJGD) kemudian dilakukan perhitungan antara ratarata tengah dan perlakuan P0 dibandingkan dengan Perlakuan P1 didapatkan hasil 47,333lebih besar dari Uji Duncan 5\% $(125,2)$ maka perbedaan yang diamati signifikan. P0 dibandingkan dengan perlakuan P2 didapatkan hasil 45,667 lebih besar Uji Duncan 5\% $(130,7)$ maka perbedaan yang diamati signifikan. P0 dibandingkan dengan perlakuan P3 didapatkan hasil 68,000 lebih besar Uji Duncan 5\% $(133,4)$ maka perbedaan yang diamati signifikan.

\section{PEMBAHASAN}

Hasil dari Uji homogenitas varian menunjukkan dari keempat perlakuan tersebut efektifitas fitoremediasi tanaman semanggi air memiliki varians yang sama atau bisa disebut (identik) homogen dengan nilai signifikan 0,034 >0,05. Hasil analisis sidik ragam menunjukkan bahwa $\mathrm{H}_{0}$ yang menyatakan Tanaman Semanggi Air (Marsilea crenata) memiliki efektifitas terhadap fitoremediasi kadar TSS limbah cair tahu ditolak, maka $\mathrm{H}_{1}$ yang menyatakan Tanaman Semanggi air (Marsilea crenata) memiliki efektivitas terhadap kadar TSS limbah cair tahu diterima dengan nilai $F_{\text {hitung }}$ 573)> F tabel 5\% $(4,07)$ serta saat dilakukan Uji lanjut dengan menggunakan Uji Duncan menunjukkan bahwa antara perlakuan menunjukkan hasil signifikan. 
Biomassa yang paling efektif dalam menurunkan kadar TSS pada limbah cair tahu adalah Biomassa 75 gram (P3) dengan presentase penurunan mencapai $43 \%$ sedangkan pada Biomassa 0 gram, 25 gram, 50 gram dan 75 gram terjadi penurunan $(221,3 ; 263$; dan 200,7). Hasil tersebut menunjukkan cukup efektifnya dalam penggunaan Semanggi air sebagai agen fitoremidiator dalam pengolahan limbah cair tahu. Menurut Haberl dan Langergrabel (2002) bahwa proses fotosintesis pada tanaman cattail memungkinkan adanya pelepasan oksigen pada akar (zona rhizosphare).

$\mathrm{pH}$ kadar TSS pada hari pertama $\mathrm{pH}$ awal limbah cair tahu 4 dan selama 10 hari $\mathrm{pH}$ mendajadi 7,3. Nilai $\mathrm{pH}$ sangat mempengaruhi proses biokimia dalam perairan, misalnya proses nitrifikasi akan berakhir jika pH rendah. Dalam Effendi, 2003 $\mathrm{pH}<4$ sebagian besar tumbuhan air mati karena tidak dapat bertoleransi terhadap $\mathrm{pH}$ rendah.

Hasil penelitian kadar TSS (Total Suspended Solid) padatan tersuspensi atau zat padat yang ukurannya partikel maksimum. Limbah cair tahu dari kekeruhannya pada air bisa disebabkan oleh adanya zat padat tersuspensi. Dari warna air limbah yang keruh hal ini dapat menyebabkan terhalangnya sinar matahari masuk ke dalam air limbah yang sedang mengalami pengolahan sehingga terhambatnya proses fotositesis dan berkurangnya kadar oksigen dalam air.

Jika oksigen hanya sedikit maka bakteri aerobik akan cepat mati karena suplai oksigennya sedikit dan bakteri anaerobik mulai tumbuh. Bakteri anaerobik akan mendekompisisi dan menggunakan oksigen yang disimpan dalam molekul-molekul yang sedang dihancurkan. Hasil dari kegiatan bakteri anaerobik dapat membentuk hidrogen sulfida $\left(\mathrm{H}_{2} \mathrm{~S}\right)$, gas yang berbau busuk dan berbahaya, serta beberapa produk lainnya. Polutan dalam limbah cair tahu dalam bentuk padatan yang tinggi dapat mempengaruhi lingkungan perairan seperti TSS Hal ini menurut Mispar (2001), karena dapat mengurangi penetrasi cahaya matahari ke dalam badan air, sehingga menyebabkan gangguan pertumbuhan organisme.

Tanaman Semanggi air yang digunakan untuk proses fitoremediasi tetap mampu hidup tumbuh dan berkembang pada lingkungan tercemar limbah cair tahu. Hal ini dikarenakan tanaman Semanggi air sebagai agen fitoremidiator menggunakan limbah tersebut sebagai sumber nutrisi untuk berkembang. Hal tersebut sesuai dengan hasil penelitian yang telah dilakukan oleh Oyedeji et al. (2013) menyatakan bahwa minyak bumi yang telah terurai dan diserap oleh tanaman dengan agen fitoremidiator berfungsi sebagai nutrisi untuk tumbuh dan berkembang. Pada penelitian yang telah dilakukan oleh Xia et al. (2004) terhadap tanaman V.zizanioides mampu hidup dan tumbuh subur pada lingkungan yang tercemar dibandingkan dengan yang tumbuh pada perairan yang bersih. Keberadaan minyak bumi dalam air yang semakin berkurang, dapat juga dilihat dari warna air dalam percobaan yang semakin minggu semakin jernih.

\section{SIMPULAN}

Tanaman semanggi air (Marsilea crenata) efektif sebagai agen fitoremediasi terhadap penurunan kadar TSS pada limbah cair tahu dengan 0 gram, 25 gram, 50 gram, 75 gram.

\section{SARAN}

1. Perlu dilakukan penelitian lebih lanjut tentang kemampuan tanaman semanggi air dalam menurunkan zat polutan yang lainnya sehingga ada penelitian lanjutan yang berkaitan dengan bioremediasi tanaman semanggi air.

2. Perlu adanya penelitian menggunakan agen fitoremediasi yang berbeda sehingga diharapkan dapat menghasilkan inovasi baru dan dapat dijadikan solusi bagi industri-industri dalam pengolahan limbah secara alami.

\section{DAFTAR PUSTAKA}

Aslam, A. F. (2017). Fitoremediasi Air Limbah Tahu dengan Media Enceng 
Gondok (Eichornia crassipes) pada Reaktor Paralel. Skripsi.

Faisal, M., Mulana, F., Gani, A., Daimon, H., 2015. Physical and chemical properties of wastewater discharged from tofu industries in Banda Aceh City, Indonesia. Res. J. Pharm. Biol. Chem. Sci. 6, 1053-1058.

Gupta, S., Nayek, S., Saha, R. N., \& Satpati, S. 2008. Assesment Of Heavy Metal Accumulation In Macrophyte, Agriculture Soil, And Crop Plants Adjacent To Discharge Zone Of Sponge Iron Factory. Environmental Geology 55(4), 731-739.

Haberl R. and Langergraber H. 2002. Constructed wetlands: a chance to solve waste water problems in developing countries. Wat. Sci Technol.

Mcfarland, D. G., L. S. Nelson, M. J. Grodowitz, R. M. Smart, C. S. Owens. 2004. Pistia Stratiotes L. D. S. Mitchell (Giant Salvinia) In The United States : A Review Of Species Ecology And Approaches To Management. U.S. Army Corps Of Engineers Wasington, D.C 203141000.

Mispar, M. 2001. Sebaran Bahan Organik dan Total Padatan Tersuspensi di sekitar Perairan Pantai Losari Kota Makassar Sulawesi Selatan. Skripsi. Fakultas Ilmu kelautan dan Perikanan. Universitas Hasanuddin Makassar

Oyedeji, S., Raimi, I. O., \& Odiwe, A. I. (2013). A comparative assessment of the crude oil-remediating potential of Cynodon dactylon and Eleusine indica. Environmental and Experimental Biology, 11, 145-150.

Popova, L. P., Maslenkova, L. T., Yordanova,

R. Y., Ivanova, A. P., Krantev, A. P., Szalai, G., \& Janda, T. 2009. Exogenous Treatment With Salicylic Acid Attenuates Cadmium Toxicity In Pea Seedlings. Plant Physiology And Biochemistry, 47(3), 224-231.

Safitri, R. 2009. Phytoremediasi Greywater Dengan Tanaman Kiambang (Pistia Stratiotes) Dan Tanaman Kiambang (Pistia Stratiotes L.) Serta Pemanfaatan Untuk Tanaman Selada (Lactuca Sativa) Secara Hidroponik. Institut Pertanian Bogor.

Seth, C. S., Misra, V., Chauhan L, K. S., \& Singh, R. R. 2008. Genotoxicity Of Cadmium On Root Meristem Cells Of Allium Cepa: Cytogenetic And Comet Assay Approach. Ecotoxicology And Environmental Safety 71(3), 711-716.

Surtikanti,H.K. 2011. Isolasi Dan Identifikasi Bakteri Yang Berpotensi Sebagai Agen Bioremediasi Timbal (Pb) Dari Lumpur Lapindo. Skripsi Tidak Diterbitkan.

Subekti, S. 2011. Pengolahan Limbah Cair Tahu Menjadi Biogas Sebagai Bahan Bakar Alternatif. Skripsi, Program Studi Ilmu Lingkungan, Universitas Padjajaran, Semarang.

Widyaningsih, V. (2011). Pengolahan Limbah Cair Kantin Yogma Fisip UI. Sripsi. Program Studi Teknik Lingkungan UI. Depok.

Xia, H. P., Liu, S. Z., \& Ao, H. X. (2004). Study on purification and uptake of vetiver grass to garba 